\title{
Induced Polyploidy: A Tool for Forage Species Improvement
}

\author{
Saeed Rauf ${ }^{1}$ (D) , Rodomiro Ortiz ${ }^{2, * \mathbb{D}}$, Dariusz P. Malinowski ${ }^{3}$, Wellington Ronildo Clarindo ${ }^{4}$, Wardah Kainat ${ }^{1}$, \\ Muhammad Shehzad ${ }^{1}$, Ummara Waheed ${ }^{5}$ and Syed Wasim Hassan ${ }^{1}$
}

1 Department of Plant Breeding and Genetics, College of Agriculture, University of Sargodha, Sargodha 40100, Pakistan; saeedbreeder@hotmail.com (S.R.); wardahkainat66@gmail.com (W.K.); muhammad.shehzad@uos.edu.pk (M.S.); whsyed61@gmail.com (S.W.H.)

2 Department of Plant Breeding, Swedish University of Agricultural Sciences, Sundsvagen 10 Box 101 , SE 23053 Alnarp, Sweden

3 Texas A\&M AgriLife Research, Texas A\&M University, P.O. Box 1658, Vernon, TX 76385, USA; dmalinow@ag.tamu.edu

4 Department of General Biology, Federal University of Viçosa, Viçosa MG 36.570-900, Brazil; welbiologo@gmail.com

5 Institute of Biotechnology and Plant Breeding, MSN-University of Agriculture, Multan 59920, Pakistan; ummara.waheed@mnsuam.edu.pk

* Correspondence: rodomiro.ortiz@slu.se; Tel.: +46-40415527

Citation: Rauf, S.; Ortiz, R.;

Malinowski, D.P.; Clarindo, W.R.;

Kainat, W.; Shehzad, M.; Waheed, U.; Hassan, S.W. Induced Polyploidy: A Tool for Forage Species Improvement. Agriculture 2021, 11, 210.

https:/ / doi.org/10.3390/agriculture 11030210

Academic Editor: Ioannis Tokatlidis

Received: 5 January 2021

Accepted: 28 February 2021

Published: 4 March 2021

Publisher's Note: MDPI stays neutral with regard to jurisdictional claims in published maps and institutional affiliations.

\section{Copyright: (c) 2021 by the authors.} Licensee MDPI, Basel, Switzerland. This article is an open access article distributed under the terms and conditions of the Creative Commons Attribution (CC BY) license (https:// creativecommons.org/licenses/by/ $4.0 /)$.

\begin{abstract}
Polyploidy means having more than two basic sets of chromosomes. Polyploid plants may be artificially obtained through chemical, physical and biological ( $2 n$ gametes) methods. This approach allows an increased gene scope and expression, thus resulting in phenotypic changes such as yield and product quality. Nonetheless, breeding new cultivars through induced polyploidy should overcome deleterious effects that are partly contributed by genome and epigenome instability after polyploidization. Furthermore, shortening the time required from early chromosome set doubling to the final selection of high yielding superior polyploids is a must. Despite these hurdles, plant breeders have successfully obtained polyploid bred-germplasm in broad range of forages after optimizing methods, concentration and time, particularly when using colchicine. These experimental polyploids are a valuable tool for understanding gene expression, which seems to be driven by dosage dependent gene expression, altered gene regulation and epigenetic changes. Isozymes and DNA-based markers facilitated the identification of rare alleles for particular loci when compared with diploids, and also explained their heterozygosity, phenotypic plasticity and adaptability to diverse environments. Experimentally induced polyploid germplasm could enhance fresh herbage yield and quality, e.g., leaf protein content, leaf total soluble solids, water soluble carbohydrates and sucrose content. Offspring of experimentally obtained hybrids should undergo selection for several generations to improve their performance and stability.
\end{abstract}

Keywords: amphiploidy; disomic polyploidy; synthetic polyploidy; plant genome evolution; polysomic polyploidy

\section{Introduction}

Polyploidy, which occurs among various life forms [1], allows having more than two basic sets of chromosomes. It is a widely distributed phenomenon in wild and cultivated species in agriculture, forests and rangelands [2]. Whole genome duplications take place at very high rate in forages, e.g., $75 \%$ of the speciation underwent genome duplications in group of 1200 species [3].

The remarkable ecological success of the polyploidy prompts breeders to develop new polyploid germplasm with increased economic value [2]. These polyploids could assist on understanding the evolution of various plant species with economic relevance. Polyploids are also used as bridge species to transfer resistant genes from their parental species [4,5]. In contrast to natural polyploidy arising from natural selection [6], induced polyploid (polysomic polyploids, 
and true or segmental amphidiploids mainly result from the anti-tubulin effect of colchicine ((S)$\mathrm{N}$-(5,6,7,9-tetrahydro-1,2,3,10-tetramethoxy-9-oxobenzo[a]heptalen-7-yl) acetamide; and also of oryzalin (3,5-dinitro- $\mathrm{N}^{4}, \mathrm{~N}^{4}$ - dipropylsulfanilamide), trifluralin $(\alpha, \alpha, \alpha$-trifluoro-2,6-dinitro$\mathrm{N}, \mathrm{N}$,-dipropyl-p-toluidine) and amiprophos methyl (O-methyl O-(2-nitro- $p$-tolyl) $\mathrm{N}$-isopropyl phosphoramidothionate) [7].

The use of artificial polyploidy began in 1937 after the discovery and extraction of the natural compound colchicine, which has the ability to inhibit spindle fiber formation to arrest the chromosome, thus causing a failure of chromatid disjunction [8] and of cytokinesis [7]. Spontaneous chromosome set doubling also occurs in plant somatic cells, and gametes at low frequency, which may subsequently result in a polyploid organism [9] by vegetative or seminal propagation, respectively.

Natural and induced polyploid have been widely investigated in crops, trees, ornamentals, forages and medicinal plants [10]. This literature search and synthesis were pursued to address 21st century challenges related to continuous population growth, as well as the global climate change [11]. Forages are widely exploited for their vegetative biomass that may be used as animal feed or for biofuel [12]. Polyploidy is widely distributed phenomenon among forage species $[3,13,14]$. It may be induced in diploid species to improve biomass productivity and its nutritional characteristics. We review herein various methods for developing polyploid forage germplasm with chemicals and their commercial importance when compared with ancestral and natural polyploid species.

\section{Production of Polyploid Plants}

Polyploid plants (polysomic polyploids, true, and segmental amphidiploids) can be produced using various chemicals, such as colchicine, amiprophos-methyl, trifluralin or oryzalin; or physical methods such as temperature shock and protoplast fusion [8]. The most common chemical is colchicine obtained from Colchicum autumnale $\mathrm{L}$., which has an inhibitory effect on the spindle formation, causing a failure during anaphase disjunction [8] and cytokinesis [7], thus resulting in one cell with the doubled chromosome set. Hence, colchicine treatment results in either pure polyploid individuals or impure (mixoploid or aneuploid cells), depending upon the colchicine concentration and exposure time, plant tissues and its development stage, and method for chromosome set doubling. The colchicine solution may be applied to immature buds, resulting in unreduced reproductive cells and, subsequently, producing polyploidy seed at different rates. It is applied to the pedicel of growing immature bud or the inflorescence stalk may be dipped in a growth media solution with low concentration of colchicine (0.01 to $0.1 \%$ ), depending upon the forage species (Table 1). Cotton swab dipped in colchicine solution of $0.2 \%$ for $10 \mathrm{~h}$ during 2 consecutive days successfully induced a polysomic tetraploid $(12-40 \%)$ in guar accessions [15]. Colchicine can also be applied to the callus; i.e., cell culture of meristematic tissues to produce chimeric plants, or seed may be germinated in a colchicine solution [16]. Generally, colchicine $(0.1-1 \%)$ has been applied to seeds for $24-48 \mathrm{~h}$ depending upon the forage species to target cells undergoing mitosis (Table 1). Growth arrest is the first symptoms of successful application of colchicine (Figure 1). Affected cells usually resume division after a lag period of colchicine application. A comparison of euploid series $(2 \times, 4 \times, 6 \times$ and $8 \times)$ in thale cress (Arabidopsis thaliana L. Heynh.) showed that induced polyploidy had slower growth, enlarged cell size, and decreased the number of cells per leaf blade. Polyploid cells had lower lignin and cellulose but higher pectin and hemicelluloses in the stem [17]. Frequency of polyploidy induction can increase by rising colchicine concentration (Table 1). A high colchicine concentration has been, however, toxic to cell and plant tissues. A low colchicine concentration $(0.1 \%)$ treatment with relative long duration $(48 \mathrm{~h})$ has been effective in increasing the yield of polyploid cells in shoot tips in vitro [18] (Table 1). For example, sorghum (Sorghum bicolor (L.) Moench.) seed were subjected to $0.2 \%$ concentration of colchicine for $48 \mathrm{~h}$ and $72 \mathrm{~h}$, yielding $3.3 \%$ and $2.3 \%$ polysomic tetraploid plants, respectively [19]. A direct application of colchicine by dipping the apical 
meristem of seedlings produced chimeric tissues where induced polyploidy was limited to a particular layer [20].

Polyploid plants can ensue from somatic cell fusion [21]. This method has been used to fuse protoplast of the same species (polysomic polyploidy) or from two species (amphiploidy or disomic polyploidy) in an electric shock chamber without reduction division, thus obtaining amphidiploid forage species [22].

In vitro induction of polyploidy was successfully achieved by culturing the nodal segments or callus in tissue culture media supplemented with a low concentration of colchicine. This method induces high polyploidy frequency in various species (Table 1). Although other chromosome doubling agent such as, oryzalin had a higher frequency of induced polyploidy than colchicine [23], it inhibited callus growth and seedling regeneration. Liquid medium was more effective in inducing polyploidy than semi solid media $[7,23]$. A concentration of $5 \mu \mathrm{m}$ oryzalin was more effective than colchicine and trifluralin in inducing chromosome doubling of calli obtained from interspecific hybrid plants of elephant grass $\times$ pearl millet [24]. In vitro treatment of red clover (Trifolium pratense L.) yielded 55.5\% more polysomic tetraploids and 1.9 times fewer chimeric individuals than imbibition of seed in a colchicine solution $[25,26]$. Colchicine, amiprophosmethyl and oryzalin produced similar frequency of polysomic tetraploid (31-47\%) and chimeric plants (14-22\%) in T. pratense [25]. Colchicine $(0.015 \%$ in tissue culture media) was more effective than oryzalin in inducing polysomic tetraploidy (16\%) in peanut clover (Trifolium polymorphum Poir.) [27].

The demand for pure polyploids with different ploidy levels obtained after chromosome doubling needs screening, selection and periodic evaluation of the ploidy level stability of the natural and induced [28]. Nowadays, the main method used for this purpose is flow cytometry $[8,29]$, which increases the efficiency of DNA ploidy level determination and nuclear genome size measurement. With flow cytometry large numbers of individuals are quickly evaluated in only one day using a quantitative, rapid, reliable and reproducible method [11]. This powerful screening tool for ploidy level has been very useful in forage breeding programs. However, chromosome counting, which is performed through microscopic observation of the metaphase cells, has been applied to confirm the chromosome number $[8,28,29]$, and to detect eventual aneuploids. Besides these direct tools, indirect analyses have also been accomplished. The effects of induced polyploidy on forage species were noted as an increase in the stomatal area and a decrease in the stomatal frequency. These changes in leaf anatomy arose after expanding cell volume due to increasing nuclear DNA content [30].

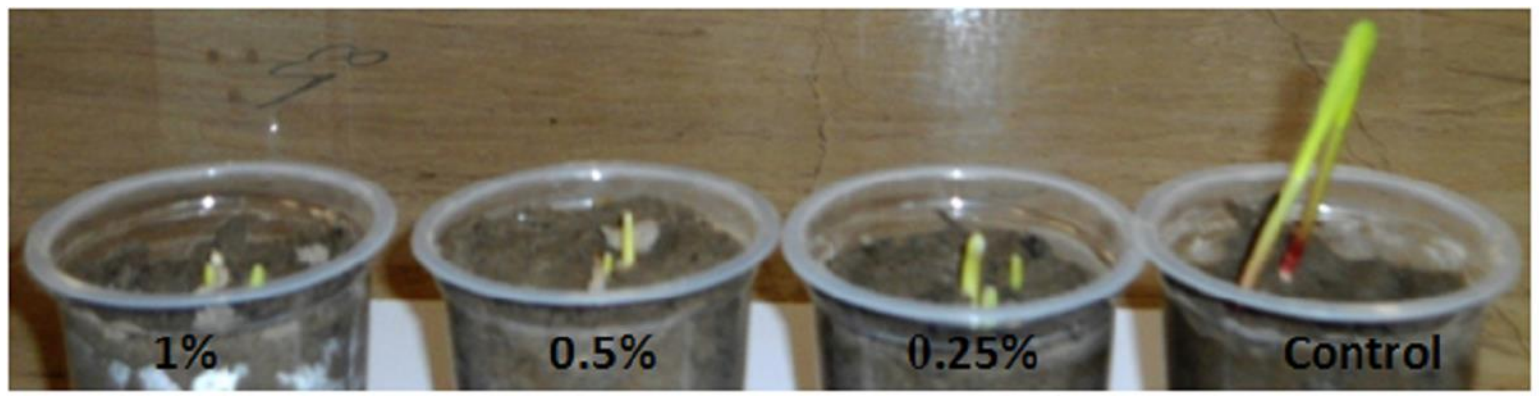

Figure 1. Control vs. various treatments of colchicine $(0.25-1 \%)$ in growth of interspecific maize $\times$ teosinte seedlings after treatment of seeds for $24 \mathrm{~h}$ (Niazi, I.A.K., permission granted) [38]. 
Table 1. Recovery of induced tetraploids using various concentrations of anti-mitotic treatments.

\begin{tabular}{|c|c|c|c|c|}
\hline Species & Ploidy Level & Treatment & Polyploid Frequency & References \\
\hline Vicia faba L. & $2 \times=12$ & $0.005 \%$ for $8 \mathrm{~h}$, seed imbibition & $4 \times=50 \%$ & [31] \\
\hline $\begin{array}{l}\text { Cyamopsis tetragonoloba } \mathrm{L} \text {. } \\
\text { Taub. }\end{array}$ & $2 \times=14$ & $0.2 \%$ cotton swab for $10 \mathrm{~h}$ & $4 \times=12-40 \%$ & [15] \\
\hline $\begin{array}{l}\text { Brachiaria decumbens (Mez) } \\
\text { Davidse }\end{array}$ & $2 \times=18,36,45$ & $\begin{array}{l}\text { Colchicine concentration } \\
(0.01 \%, 0.01 \% \text {, and } 0.1 \%)\end{array}$ & $\begin{array}{l}0.1 \% \text { colchicine for } 48 \mathrm{~h} \\
\text { induces } 11 \% \text { of polyploid }\end{array}$ & [20] \\
\hline Psathyrostachys juncea (Fisch.) & $2 \times=14$ & $100 \mathrm{mg} \mathrm{L}^{-1}$ colchicine and & $4 \times=53.58 \%$ & {$[30]$} \\
\hline Nevski & & $1.5 \%$ DMSO, callus tissue & $\begin{array}{l}\text { Stomata size increased by } \\
13.52 \% \text { while stomata } \\
\text { frequency decreased }\end{array}$ & \\
\hline Lolium multiflorum Lam. & $2 \times=14$ & $\begin{array}{l}\text { Seedling immersion }(0.2 \%) \text { for } \\
3 \mathrm{~h} \text { and } 24 \mathrm{~h} \text { in colchicine }\end{array}$ & $4 \times=20 \%$ & {$[32]$} \\
\hline Sorghum bicolor (L.) Mönch & $2 \times=20$ & $\begin{array}{l}\text { MS medium supplemented } \\
\text { with } 0.1 \% \text { of colchicine }\end{array}$ & $\begin{array}{l}\text { In vitro media supplemented } \\
\text { with } 0.1 \% \text { colchicine has the } \\
\text { highest frequency } 4 \times \\
\text { induction }\end{array}$ & [18] \\
\hline Sorghum bicolor (L.) Mönch & $2 \times=20$ & $\begin{array}{l}4 \text { colchicine levels and } 5 \\
\text { soaking times }\end{array}$ & $\begin{array}{l}0.2 \% \text { concentration for } 48 \mathrm{~h} \\
\text { had ploidy induction of } 3.8 \\
\text { to } 4.2 \% \text { colchicine }\end{array}$ & [19] \\
\hline Trifolium pratense L. & $2 \times=14$ & Callus vs. seed germination & Amiprophos-methyl and & [25] \\
\hline Trifolium hybridum L. & $2 \times=16$ & $\begin{array}{l}\text { treatment of colchicine, } \\
\text { amiprophos-methyl, trifluralin } \\
\text { and oryzalin }\end{array}$ & $\begin{array}{l}\text { oryzalin had similar } \\
\text { frequency of ploidy } \\
\text { induction in T. pratense; } \\
\text { colchicine had higher } \\
\text { efficiency for induction of } \\
\text { tetratploid in T. hybridum }\end{array}$ & \\
\hline Panicum virgatum $\mathrm{L}$. & $4 \times=36$ & $\begin{array}{l}0.2 \% \text { colchicine solution } \\
\text { applied to seed }\end{array}$ & $8 \times=19$ families & {$[33]$} \\
\hline $\begin{array}{l}\text { Pennisetum purpureum } \\
\text { Schumach. } \times \text { Pennisetum } \\
\text { glaucum (L.) Brown }\end{array}$ & $3 \times=21$ & $\begin{array}{l}\text { In vitro colchicine }(0.1 \%) \\
\text { solution, seed imbibition }\end{array}$ & $\begin{array}{l}6 \times=17 / 480, \text { larger stomata } \\
\text { size }\end{array}$ & {$[34]$} \\
\hline $\begin{array}{l}\text { Brachiaria ruziziensis (Mez) } \\
\text { Davidse }\end{array}$ & $2 \times=18$ & In vitro $0.0125-0.1 \%$ colchicine & $\begin{array}{l}4 \times=23 / 400 \\
(31.3 \%) 0.1 \% \text { colchicine for } 3 \\
\text { BAP }\end{array}$ & [35] \\
\hline $\begin{array}{l}\text { Brachiaria ruziziensis (Mez) } \\
\text { Davidse }\end{array}$ & $2 \times=18$ & $0.1 \%$ colchicine, seed & $4 \times=11.45 \%$ & [36] \\
\hline Miscanthus species Andersson & $2 \times=38$ & $\begin{array}{l}\text { Callus treatment with } 313-626 \\
\mu \mathrm{M} \text { colchicine }\end{array}$ & $\begin{array}{l}4 \times \text { was induced with } 40 \% \\
\text { success }\end{array}$ & [37] \\
\hline
\end{tabular}

\section{Impact of Polyploidy on Forage Yield and Contributing Traits}

There are numerous positive effects of induced polyploidy when compared with diploidy in various forage species; i.e., larger leaves, herbage yield and slow decay of heterosis $[10,31]$ (Table 2), increased plant height, persistence, faster re-growth after grazing and augmented branching were noted in the former than in the latter [39] (Table 2). Potential benefits of induced polyploidy are noted in Table 2. Disomic tetraploid intersubspecific hybrids (maize (Zea mays L.) $\times$ teosinte (Z. mays spp. mexicana (Schrad.) Kuntze.)) had $14 \%$ biomass yield increase over their diploid counterpart [16]. Other advantage of tetraploid hybrids included greater leaf area, leaf essential oil contents, and protein contents [16]. Polysomic tetraploid of Lolium species had slow decay of heterosis and has the potential to give better seed yield over several generations without significant decrease in their forage yield and thus their cultivation could be done with cheaper seed that could overcome the drawback of expensive $F_{1}$ seed [40]. However, chromosome doubling reduced the persistence in the induced $4 \times$ perennial ryegrass (Lolium perenne L.) [40]. Research has shown that neo polyploids have increased production of secondary metabolites, thus enhancing forage quality, succulence and forage intake [41]. Induced polyploids had often poor seed setting and higher pollen sterility [31]. Polysomic tetraploids $(4 \times)$ were compared with 
diploids $(2 \times)$ plants in fodder vetch (Vicia villosa Roth) and induced polysomic tetraploid plants were dwarf with great leaf area and stomatal diameter, as well as high chlorophyll content, but the polysomic tetraploid had delayed and lesser flowering than diploid counterparts [42]. Reconstituted polysomic tetraploid $(4 \times)$ of meadow fescue (Festuca pratensis (Huds.) Darbysh.) had 26\% dry matter and 100\% seed yield advantage over standard check cultivars [25]. For some forage species; i.e., as slender cocksfoot (Dactylis polygama Horvat.) and perennial ryegrass, polysomic tetraploids did not differ in biomass yield from diploids but they were superior in terms of forage intake [43] and other forage quality characteristics [44]. Patents for methods of production of $4 \times$ and $4 \times$ maize has been awarded [45,46]. The triploid $(3 \times$ superior over $4 \times$ and $2 \times$ ) maize has been used to produce high molasses, rum and fodder in low sterile genotype [46].

Table 2. Impact of induced polyploidy on forage traits in various species.

\begin{tabular}{|c|c|c|}
\hline Species & Characteristics & References \\
\hline $\begin{array}{l}\text { Zea mays L. } \times \text { Zea mays ssp. mexicana (Schrad.) } \\
\text { Kuntze }\end{array}$ & $\begin{array}{l}4 \times \text { had higher leaf soluble proteins, oil contents, and total } \\
\text { soluble sugars }\end{array}$ & [16] \\
\hline Sorghum bicolor (L.) Mönch & $\begin{array}{l}4 \times \text { had higher chlorophyll contents, water soluble } \\
\text { carbohydrates, and proteins }\end{array}$ & [18] \\
\hline $\begin{array}{l}\text { Lolium multiflorum Lam., Lolium perenne L. and } \\
\text { Festuca pratensis (Huds.) Darbysh. }\end{array}$ & $\begin{array}{l}4 \times \text { produced higher dry matter and seed yield when } \\
\text { compared with } 2 \times \text { and may be used for the development of } \\
\text { new cultivars }\end{array}$ & [26] \\
\hline Trifolium alexandrinum $\mathrm{L}$. & $\begin{array}{l}\text { Induced } 4 \times \text { had taller plants, faster regrowth, increased } \\
\text { tillering and branching }\end{array}$ & {$[39]$} \\
\hline Lolium perenne L. & $\begin{array}{l}4 \times \text { had larger and wider leaves, taller seedlings, and fewer } \\
\text { tillers }\end{array}$ & [47] \\
\hline Sorghum bicolor (L.) Mönch & $\begin{array}{l}4 \times \text { pollen had lower germination percentage and pollen } \\
\text { tube growth than diploid pollens resulting in lower seed } \\
\text { setting percentages }\end{array}$ & [48] \\
\hline Sorghum bicolor (L.) Mönch & $\begin{array}{l}4 \times \text { had thicker leaves, taller plantslonger leaves, higher } \\
\text { antioxidant activity, panicle length and diameter }\end{array}$ & [49] \\
\hline Trifolium alexandrinum $\mathrm{L}$. & $4 \times$ had better pentafoliate trait than $2 \times$ & {$[50]$} \\
\hline Cynodon dactylon Pers. & $\begin{array}{l}\text { Stomatal size increased while stomatal density decreased. } \\
\text { Leaf anatomy was used to discriminate } 2 \times \text { vs. } 3 \times \\
\text { accessions }\end{array}$ & {$[51]$} \\
\hline
\end{tabular}

$2 \times=$ diploid, $3 \times=$ triploid, $4 \times=$ tetraploid.

\section{Genetics of Polyploidy}

Polysomic polyploid species differ from disomic polyploid (or amphidiploid) species due to their inheritance. The amphidiploid species show peculiar disomic inheritance for locus behaves similar to diploids. Polysomic tetraploid species show quadrivalent (multivalent) pairing, which requires chromosome homology and may end up in double reduction during meiosis II [52]. Polysomic polyploids may have four copies of alleles (Figure 2), of which the two extra copies of alleles may be useful for evolution because these alleles may undergo the process of sub-functionalization or neofunctionalization In the former, redundant alleles may mutate and be subsequently selected during evolution to achieve subfunctions in metabolic pathways but retaining the original ancestral functions, while redundant alleles may mutate and be subsequently selected during evolution to achieve new function of gene related to metabolic pathway in the latter [53]. Sub-functionalization and neofunctionalization of alleles may lead to homoeologous chromosomes that may enhance preferential pairing of fully homologous chromosome, thereby leading to suppression of quadrivalent pairing. 


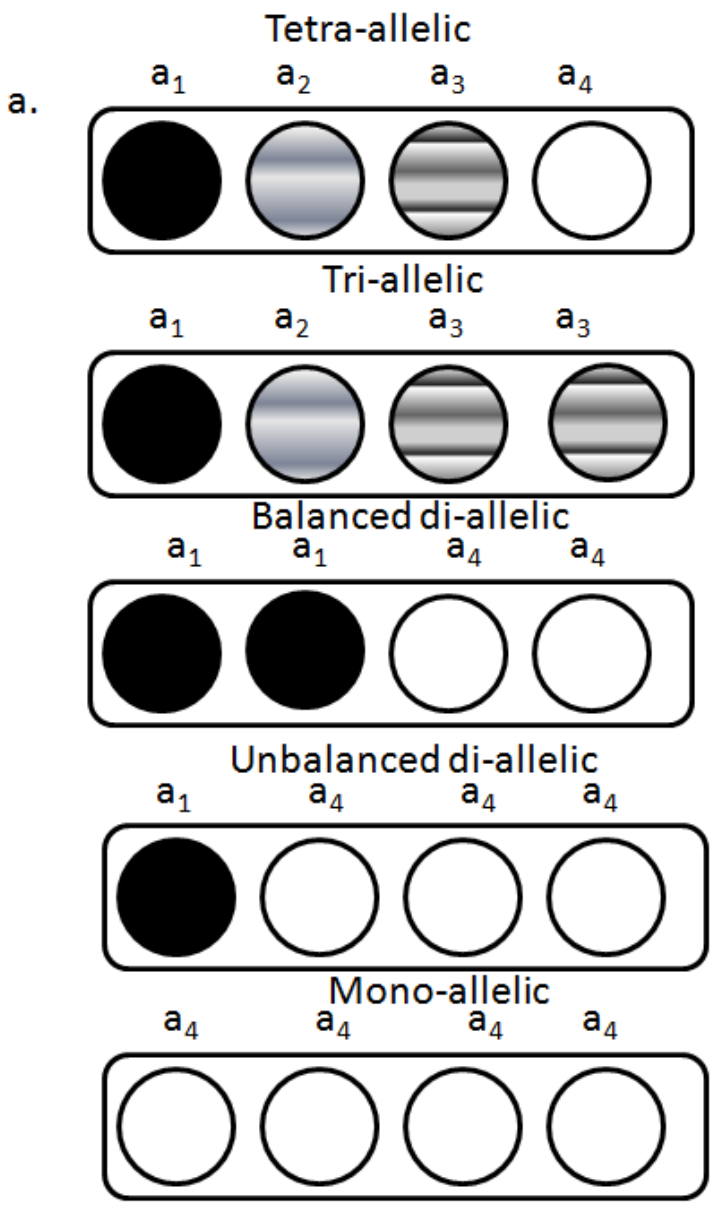

Tetrasomic inheritance

Figure 2. Polysomic tetraploid genotypes assuming sub-functionalization (a) and genotypes following disomic inheritance in a diploid (b).

There is always a challenge for a forage breeder to identify various tetrasomic genotypes (i.e., AAAA (quadriplex), AAAa (triplex), AAaa (duplex), Aaaa (simplex) and aaaa (nulliplex)) and confirm polysomic tetraploidy. Isozyme analysis in ryegrass using aspartate aminotransferase and NAD-specific aromatic alcohol dehydrogenase showed two alleles per locus and was used to distinguish heterozygous or homozygous genotypes due to co-dominance of these alleles [54]. Hence, these isozymes were only able to uncover two alleles per locus in the polyploid ryegrass. Isozyme analysis showed allelic diversity due to polymorphism in enzymatic structure that may differentiate various tetrasomic genotypes in various polysomic tetraploid alfalfa (Medicago sativa L.) populations [55]. Esterase enzyme characterized alfalfa synthetic populations into tri-allelic $\left(b_{1} b_{2} b_{3}\right)$ and di-allelic $\left(\mathrm{b}_{3} \mathrm{~b}_{3} \mathrm{~b}_{3} \mathrm{~b}_{2}, \mathrm{~b}_{3} \mathrm{~b}_{3} \mathrm{~b}_{1} \mathrm{~b}_{1}\right)$ at locus EST-B [55]. Phosphoglucomutase (PGM) is controlled by two loci (Pgm-1 and Pgm-2) while Isocitrate dehydrogenase is controlled by a single locus (IDH). Each locus shows tetrasomic inheritance in polysomic tetraploid alfalfa [56]. Both enzymes show diversity in their maker allele size and are successfully used for identification of tetrasomic genotypes in alfalfa [56]. Tetraploid alfalfa contained three alleles ( $a^{\prime}, a$ and $\left.b\right)$ for $p g m-1$. Polysomic tetraploid genotypes had the rare allele a' that was absent in diploids, but available in various tetrasomic combinations. Genotype a'a'aa (duplex) was the most frequent. Functional diversity in isozyme alleles at single locus explains the phenotypic plasticity, high level diversity, and more heterozygosity of tetraploids than in diploids, which may provide an adaptability advantage in the former [56]. For example, isozyme allelic diversity in EST-B and POX-b2 was related with fresh leaf weight in alfalfa [57]. 
DNA-based molecular markers such as amplified fragment length polymorphisms (AFLP) were used to confirm tetrasomic inheritance in the tetraploid forage legume species bird's-foot trefoil (Lotus corniculatus L.), which show suppressed quadrivalent pairing. AFLP successfully confirmed the tetrasomic inheritance prevailing in this species [58]. Similarly, tetrasomic inheritance was also evident in the other forage species such as alfalfa and bahiagrass (Paspalum notatum Fluggé) using DNA-based molecular markers systems [59-61]. Microsatellite (SSR) markers MAA660456, MTIC343, MTIC354, MTIC365 have four alleles at specific loci in polysomic tetraploid alfalfa cultivars. MTIC365 was tetra-allelic (ABCD) and tri-allelic (ABCC) in alfalfa cultivars 'Mercedes4.11' and 'Magali2', respectively [60].

Polysomic tetraploids are difficult to handle as breeding material and show low decay of heterozygosity, a high degree of inbreeding depression and disomic — tetrasomic inheritance of alleles at single locus [16,62]. The use of DNA-based molecular markers may identify various tetrasomic genotypes, could further used to select appropriate parental breeding lines. Marker-aided breeding may assist exploiting maximum heterozygosity at single loci to improve the performance of tetraploid genotypes.

The genome of polyploid species is more complex than that of diploid species. Therefore, identification of single nucleotide polymorphism (SNP)-based markers resulting from next generation sequencing brings challenges. For example, the depth of sequencing and review of the panels are several-fold higher in polyploid species than in diploid species. Distinguishing between homologues or homeologues SNP alleles in sub-genomes of amphidiploids is a complex and difficult task. Understanding homeologues relationships between various SNP alleles of a sub-genome may facilitate understanding the intergenomic interactions affecting quantitative traits.

\section{5. "OMICS" Analysis of Polyploidy}

Transcriptomic and proteomics were utilized to understand the mechanisms underlying the vegetative advantage of polyploidy in a forage species such as alfalfa $[63,64]$. Comparison of $2 \times$ and $4 \times$ bilateral sexual polyploidy of Medicago sativa L. showed 341 gene differentially expressed between $2 \times$ and $4 \times$ versions of this species. These genes were regarded as polyploidization sensitive. Metabolic comparison between forage plants with distinct ploidy level was accomplished [65]. In comparison to diploid alfalfa, authors evidenced that polysomic tetraploid $(4 \times)$ and polysomic octoploid $(8 \times)$ protoplasts showed the respective nuclear genome size, and, consequently, higher amount of the ribulose-1,5-bisphosphate carboxylase/oxygenase and chlorophyll. It seems that polyploid species had high gene and protein expression for photosynthesis. For non-forage species, the evaluations about transcriptome and physiology effects after induced chromosome set doubling have been also performed.

In addition to morphologic changes, the ornamental Lilium distichum Nakai polysomic tetraploids showed higher stomatal conductance than those remaining diploids, while L. cernuum Komar. polysomic tetraploids presented lower stomatal conductance [30]. An increase in chlorophyll content was also detected in polyploids, which resulted in darker green leaves [66]. The "gigas effect" on morphological and physiological traits of polysomic tetraploids in root vegetable radish (Raphunus sativus L.) was confirmed after comparing it to its diploid forms. There were also differences in endogenous phytohormone levels and flowering genes expression carried out to delay flowering and bolting in polysomic tetraploids [67]. Rao et al. [4] reported that induced polysomic tetraploid plants in Russian box thorn (Lycium ruthenicum Murray) — used for curing blindness in camels, exhibited more abscisic acid content that its diploid counterparts due to doubled gene copy and upregulated of the 9-cis-epoxycarotenoid dioxygenase 1 and 9-cis-epoxycarotenoid dioxygenase 2 genes involved with this hormone biosynthesis. The increase in abscisic acid in the polysomic tetraploids also upregulated the ABRE-binding factor 5-like gene and genes that codified osmotic proteins, increasing their drought tolerance vis-à-vis that of diploids. Induced polyploidy resulted in epigenetic outcomes in alfalfa, thus changing the expression 
of 189 genes [63]. Bilateral sexual polyploidization was induced to generate $4 \times$ plants in Medicago sativa $\mathrm{L}$. The comparison with $2 \times$ type through micro array chip showed a change in expression of several hundred genes related to metabolic pathways [64]. Signal grass (Brachiaria (Trin.) Griseb.) possesses various polyploid species with different basic chromosome number $(x=6$ to $x=9)$. The occurence, mapping and distribution of gypsy retrotransposons in the karyotype of Brachiaria decumbens (Mez) Davidse, B. brizantha (Mez) Davidse, B. ruziziensis (Mez) Davidse and B. humidicola (Mez) Davidse evidenced that, besides the chromosome number variation, mobile elements also contributed to karyotype evolution [68]. In addition, genetic variation was showed in polyploid Paspalum species from SSR markers developed for this genus.

Forages are also affected by abiotic and biotic stresses, which calls for investigating their "omics" differences, mainly in the transcriptome and metabolome of both the ancestor diploids and their induced polyploids. Further research on induced polyploid forages may also include the analysis regarding the interference of the nuclear gene copy increase in organellar genes expression, both in the mitochondrial and plastids, as was done by Oberprieler et al. [69] in diploid, tetraploid, and hexaploid Leucanthemum spp. Mill.

\section{Restoration of Fertility}

Induced polyploidy has been used as tool to restore the fertility of interspecific hybrids with different ploidy levels or distinct genomes with similar levels, mainly homoploids and anorthoploids. Fertility of allotriploid hybrids between Napier grass (Pennisetum purpureum (L.) Brown) and pearl millet (P. glaucum (L.) Brown) was restored by germinating the seed in medium supplemented with colchicine [70]. Induced polyploidy in homoploid interspecific (Zea mays L. $\times$ Z. mays ssp. mexicana Schrud. Kuntze) hybrids resulted in higher seed yield than that of diploid crosses when subjected to selection for the regular bivalent formation in maize [16]. Caryopsis and cell size of octoploid switchgrass (Panicum virgatum L.) increased and the anatomy of the leaf tissues was changed when compared with diploid individuals, while fertility of the induced plants was decreased significantly [33]. Allotriploid hybrids of giant miscanthus (Miscanthus $\times$ giganteus J.M.Greef, Deuter ex Hodk., Renvoize) were sterile but had higher biomass potential and persistence than diploids. Poly-disomic hexaploidy was induced to restore fertility in these allotriploid hybrids and to reduce costs for hybrid seed production [23]. Induced disomic tetraploidy in maize $\times$ teosinte hybrids followed by selection for quadrivalent and bivalent formation in induced tetraploid also led to decrease in hybrid vigor decay, which was investigated throughout various generations [16].

\section{Stability of Induced Polyploidy}

Research findings suggest that many diploid plant species originated as polyploids and reversed to diploid forms due to a gradual chromosome loss during synapsis between homologous (polysomic polyploidy) or homoeologous (amphipolyploidy or disomic polyploidy) chromosomes [53]. These species failed to develop a genetic mechanism to enhance bivalent pairing and to suppress univalent or multivalent pairing of the homologous or homoeologous chromosomes. The failure of regular bivalent pairing and disjunction resulted in a larger frequency of aneuploid gametes that increased the gametophytic sterility [53].

Chromosome number counting was done in various generation following induced polyploidy. After induced tetraploid $\left(C_{1}-C_{2}\right)$, an increase in the aneuploid form in $C_{2}(55 \%)$ was observed when compared with $C_{1}(2.5 \%)$ generation [71]. In palisade grass (Brachiaria brizantha (Rich.) Webs.), failures in spindle fibers formation and absence of metaphase plate were noted in the induced polyploids, as well as micro nuclei were observed in subsequent generation showing abnormalities in meiotic divisions [72]. Homoploid Pennisetum purpureum (L.) Brown $\times$ Pennisetum glaucum (L.) Brown showed alteration in karyotypes, as chromosomal rearrangement and loss of DNA sequences, thus evidencing that interspecific hybrids showing intergenomic conflicts could lose genomic DNA [73], including genes and DNA sequences of the centromere and telomere. Contrary to these findings, induced 
polysomic tetraploids of Italian or annual ryegrass (Festuca perennis Lam. -formerly known as Lolium multiflorum Lam.) showed stability in chromosome number in subsequent generations [32]. Selection for large pollen $(2 n)$ production in red clover increased this trait from $4 \%$ in $\mathrm{C}_{1}$ to $8.9 \%$ in $\mathrm{C}_{4}$, thus increasing polysomic tetraploid production in subsequent generations [74]. Selection for genotypes with a frequent capacity for quadrivalent pairing in induced tetraploid of maize resulted in a significant reduction in aneuploids and associated pollen sterility [38]. As a result of selection for quadrivalent formation, univalent and trivalent formation significantly decreased with a corresponding increase in bivalent and quadrivalent pairing (Table 3). Selection led to an increase in seed yield, whereas herbage yield was affected in 4th generation of self-pollinated tetraploids (Table 3). Polysomic tetraploid recovery increased over various generations of selection in perennial ryegrass (i.e., $C_{1}$ had $25 \%$ tetraploid), while self-pollination $(4 \times)$ led to the recovery of $43 \%$ tetraploid [75].

Table 3. Chromosome pairing of tetraploid $(4 \times)$ offspring of maize selected for quadrivalent behavior [38].

\begin{tabular}{|c|c|c|c|c|c|c|}
\hline \multirow{2}{*}{ Progenies } & \multicolumn{4}{|c|}{ Number of } & \multirow{2}{*}{ Forage Yield (g plant ${ }^{-1}$ ) } & \multirow{2}{*}{ Seed Setting $(\%)$} \\
\hline & Univalents (I) & Bivalents (II) & Trivalents (III) & Quadrivalents (IV) & & \\
\hline S1-2x & - & 10 & - & - & $241.34^{\mathrm{b}} \pm 42.64$ & $98.13^{a} \pm 2.01$ \\
\hline$C_{1}-4 \times$ & $2.81^{\mathrm{a}} \pm 0.39$ & $1.52^{c} \pm 0.22$ & $3.11^{\mathrm{a}} \pm 0.41$ & $6.12^{d} \pm 0.37$ & $321.55^{\mathrm{a}} \pm 36.55$ & $26.19^{d} \pm 4.12$ \\
\hline$C_{2}-4 \times$ & $2.21^{b} \pm 0.42$ & $1.84^{b} \pm 0.34$ & $2.19^{b} \pm 0.29$ & $6.88^{c} \pm 0.74$ & $334.42^{\mathrm{a}} \pm 44.37$ & $29.27^{d} \pm 2.06$ \\
\hline $\mathrm{C}_{3}-4 \times$ & $1.51^{\mathrm{c}} \pm 0.21$ & $2.02^{\mathrm{a}} \pm 0.42$ & $1.14^{\mathrm{c}} \pm 0.33$ & $7.58^{b} \pm 0.52$ & $339.27^{a} \pm 36.34$ & $41.23^{c} \pm 5.01$ \\
\hline $\mathrm{C}_{4}-4 \times$ & $0.81^{\mathrm{d}} \pm 0.17$ & $2.06^{\mathrm{a}} \pm 0.27$ & $0.54^{\mathrm{d}} \pm 0.21$ & $8.32^{a} \pm 0.43$ & $351.21^{\mathrm{a}} \pm 40.19$ & $71.40^{b} \pm 3.71$ \\
\hline
\end{tabular}

Means with similar letters are not statistically different $(p \geq 0.05) . C_{1}, C_{2}, C_{3}$ and $C_{4}$ are induced polyploid $(4 \times)$ offspring self-pollinated for four subsequent generations.

\section{Stress Tolerance after Induced Polyploidy}

The benefits of induced polyploidy, including polysomic and disomic polyploidy, have been often correlated with increased abiotic and biotic stress tolerance $[75,76]$ (Table 4). Higher tolerance to stress may directly result from induced polysomic polyploidy, which can increase the allelic copies for particular loci, thus increasing gene expression and regulatory mechanisms for stress response [1]. Tetraploid species have been considered physiologically efficient due to improved gas exchange characteristics; i.e., carbon exchange rates, water use efficiency, transpiration and stomatal conductance [77] (Table 4). A natural polysomic tetraploid population of Rhodes grass (Chloris gayana L.) retained higher genetic diversity than its diploid form, which led to diversifying adaptation mechanisms to salinity stress [78]. In contrast, polysomic tetraploid perennial ryegrass had lower persistence than its diploid form due to reduced root biomass and profuse tillering [79]. However, there were no differences between the diploid and tetraploid versions of perennial ryegrass $\mathrm{cv}$. 'Alto' regarding water deficit tolerance and host plant resistance to invertebrates [79]. In another study, induced polysomic tetraploid of ryegrass resulted in high competitive ability but low tolerance to water deficit [80]. Different species of the grass genus Cenchrus differ in their ploidy; i.e., diploids, tetraploids and hexaploids. Tetraploid and hexaploid species had better gas exchange and morphological traits such as leaf rolling, wilting and plant height than diploid species [81]. Moreover, tetraploid and hexaploid species had better drought recovery than diploid species [81]. 
Table 4. Response of natural and induced polyploidy to various abiotic stress conditions and endophytic fungi interactions.

\begin{tabular}{|c|c|c|c|}
\hline Stress & Species & Resistance & Reference \\
\hline Salinity & Chloris gayana L. (Rhodes grass) & $\begin{array}{l}\text { Wild genetic diversity in tetraploid species } \\
\text { may be useful for making selection for salinity } \\
\text { tolerance }\end{array}$ & [78] \\
\hline Water stress tolerance & Eight Cenchrus species & $\begin{array}{l}\text { Morphological traits such as plant height, leaf } \\
\text { rolling and wilting indicated higher water } \\
\text { stress tolerance in natural polysomic tetraploid } \\
\text { species }\end{array}$ & [81] \\
\hline Water stress tolerance & $\begin{array}{l}\text { Lolium multiflorum Lam. and } \\
\text { Lolium perenne L. }\end{array}$ & Polyploid had better tolerance than $2 \times$ species & [82] \\
\hline $\begin{array}{l}\text { Aluminum tolerance }[16 \mathrm{mM} \\
\left.\mathrm{Al}_{2}\left(\mathrm{SO}_{4}\right)_{3}\right]\end{array}$ & 16 polyploid vs. diploid species & $\begin{array}{l}\text { Polyploidy was positively related with the } \\
\text { stress tolerance index }\end{array}$ & [83] \\
\hline Salt stress & Trigonella foenumgreaum $\mathrm{L}$. & $\begin{array}{l}\text { Induced polyploids showed higher values of } \\
\text { forage traits under salt stress }\end{array}$ & [84] \\
\hline Salinity & Brassica rapa $\mathrm{L}$. & $\begin{array}{l}4 \times \text { plant species had better germination under } \\
\text { salinity stress and maintained higher } \mathrm{K}^{+} / \mathrm{Na}^{+} \\
\text {ratio in roots and shoots }\end{array}$ & [85] \\
\hline Endophytic fungi & $\begin{array}{l}\text { Lolium multiflorum Lam. and } \\
\text { Bromus }\end{array}$ & $\begin{array}{l}2 \times \text { species had higher endophytic infection } \\
\text { rate than } 4 \times\end{array}$ & [86] \\
\hline Cold and drought stress & $\begin{array}{l}\text { Perennial ryegrass (Lolium perenne } \\
\text { L.) }\end{array}$ & $\begin{array}{l}4 \times \text { species had better tolerance to cold and } \\
\text { drought tolerance, higher regrowth and high } \\
\text { dry matter yield }\end{array}$ & [87] \\
\hline Drought stress & Perennial ryegrass & Greater biomass yield under drought stress & [88] \\
\hline
\end{tabular}

$2 \times=$ diploid, $4 \times=$ tetraploid.

Tetraploid and diploid versions of Cenchrus species also differ in the antioxidant system. The tetraploid species had more efficient and expressive antioxidant system (higher values for $\Delta^{1}$-pyrroline-5-carboxylate synthetase) to scavenge the reactive oxygen species under water stress, which may be translated in higher tolerance to water stress [81,89]. Disomic polyploidy can indirectly improve stress tolerance as the amphidiploids combining a commercially important but susceptible diploid species with a highly resistant species, followed by a doubling of the chromosome number. Triticale (Wittm. ex A. Camus. $\times$ Triticosecale) is a human-made species originating from the hybridization between tetraploid self-pollinated species wheat (Triticum durum Desf.), and diploid outcrossing species rye (Secale cereale L.), with the aim of combining the nutritional characteristics from wheat with drought and salinity stress tolerance, plus rust resistance from rye [90]. Aluminum tolerance of disomic hexaploid and octoploid triticale showed variable contribution of its parental species and could not be fully expressed in rye synthetic cultivars [91]. Chromosome set doubling in maize $\times$ teosinte hybrids improved biomass yield, tillering, and resistance to heat stress [16]. However, spotted stalk borer (Chillo partellus Swinhoe) resistance in $\mathrm{F}_{1}$ interspecific maize $\times$ teosinte hybrids was not noticed because of the effect of the susceptible maize parent [92].

\section{Species: An Example of Commercial Success of Induced Polyploidy}

The data reviewed above showed some successful examples of about the experimentally obtained polyploids. However, forage breeders considered some decades ago induced polyploidy as an unconventional technique with high expectation and low realization [93]. According to earlier research, it may take many years from the first chromosome set doubling events to the development of a superior new cultivar [93]. Lolium is a nice example showing that induced polyploidy brought commercial success of polysomic tetraploids of this species [94]. This is probably the best polyploidization result for a forage species, but it has taken well over 50 years from the early doubling events to the release of tetraploid cultivars [72]. Tetraploid cultivars of Italian ryegrass may have larger seed size, leaf size and length, plant height, seed head length than its $2 \times$ species [95]. Seed mass of $4 \times$ accessions of Lolium species was $3.8 \mathrm{mg}$ (120 seeds) versus $2.4 \mathrm{mg}$ (120 seeds) in $2 \times$ cultivars [47]. Seed 
mass affects seedling vigor and morphological traits in early growth [47]. At cellular level, $4 \times$ cultivars of Lolium had faster cell elongation rate which increase the cell length, which increased leaf size [96]. Tetraploid tissues had 20-fold larger mesophyll and epidermal cells than in tissues of diploid cultivars [96]. DNA content of $4 \times$ Lolium accessions were $11.45 \mathrm{pg}$

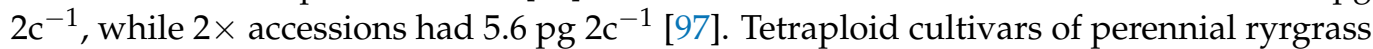
had higher digestibility and water-soluble carbohydrates [98]. These $4 \times$ cultivars of Lolium species also offer several other advantages, e.g., being cheaper for cultivation than $\mathrm{F}_{1}$ hybrid seed, or having tolerance to abiotic stresses [42] (Table 4). Drought tolerance noted in tetraploid cultivars of Italian ryegrass was due to increased production of antioxidants such as phenolics and enzymes that scavenge the reactive oxygen species under stress [99]. Tetraploid cultivars of perennial ryegrass had an advantage over diploid in late heading cultivars for traits such as herbage mass $\left(\mathrm{kg} \mathrm{DM} \mathrm{ha}^{-1}\right)$ under low stocking rate, while showing superior sward height, bulk density $\left(\mathrm{kg} \mathrm{m}^{-2}\right)$, leaf proportion under both low and high stocking rate [100]. Moreover, intermediate heading tetraploid Lolium cultivars had higher organic matter digestibility, leaf crude protein (\%) [101]. Likewise, cows fed on tetraploid cultivars had higher milk yield $\left(\mathrm{kg}_{\text {day }}{ }^{-1}\right)$, solid corrected milk yield $\left(\mathrm{kg} \mathrm{day}^{-1}\right)$ under both high and low stocking rate, while late heading tetraploid Lolium cultivars were superior under low stocking rates for same traits [100]. Fat, protein and lactose yield $\left(\mathrm{kg} \mathrm{day}^{-1}\right)$ were higher in animals fed on tetraploid Lolium cultivars under both high and low stock conditions [101].

In a top cross mating design, tetraploid open pollinated cultivars (female) were crossed with newly generated induced tetraploid plants (male testers), and several uniform hybrid offspring were established, out of which one family had better dry matter yield and watersoluble carbohydrate but lower ground cover than the check for three years [40]. In a trial over 3 years, late heading tetraploid cultivars of perennial ryegrass such as 'Ba13798' and 'Aberbite' had higher total dry matter yield $\left(\mathrm{kg} \mathrm{ha}^{-1}\right)$, dry matter digestibility, water soluble carbohydrate but lower crude protein and ground cover than late heating diploid cultivars [40]. The $4 \times$ Lolium cultivar 'Green gold' had a dry matter yield advantage of $7 \%$ per harvest and superior quality such as water-soluble carbohydrates over the diploid cultivar 'AbderDart' [101]. However, diploid cultivars had higher silage ability than the tetraploids [101]. Livestock got higher dry matter feed (1380 $\left.\mathrm{kg} \mathrm{ha}^{-1}\right)$ in, and spent more time (10\%) grazing tetraploid than diploid cultivars $\left(895 \mathrm{~kg} \mathrm{ha}^{-1}\right)$ [102]. This cattle preference for tetraploid cultivars arose due to both high leaf proportion and leaf soluble carbohydrates [102]. A study showed high water-soluble carbohydrate and crown rust susceptibility in Lolium tetraploid cultivars [103]. Recently, the late maturing cultivar 'FL-Red' was released due to its host plant improved resistance to crown rust and high sustainable yield [103]. Seed mixture of tetraploid Lolium with white clover (Trifolium repens L.) and other species also led to high dry matter yield. Induced tetraploidy had similar effect on water-soluble carbohydrates in tetraploid Lolium cultivars as that noticed after recurrent selection for high water-soluble carbohydrates in diploid cultivars [104]. Water-soluble content could be increased either by intensifying the favorable alleles through recurrent selection or increasing the copy number of alleles in tetraploid bred germplasm [105], thus suggesting additive gene action for this characteristic.

\section{Factors Affecting Commercialization of Induced-Polyploid Cultivars}

Several factors such as polyploid usefulness, polyploidy maintenance in subsequent generations, or artificial polyploids fertility may ensure success and allow polyploidy moving from being just experimental to commercialization. The economic value of artificial forage polyploids was noted as a result of their high biomass as well as increased forage quality and digestibility. Testing of across agro-ecological zones forage yield and quality of induced polyploid may be necessary to accurately judge their performance and stability after several generations of self-pollination. Concentration of spindle inhibiting agents may also need to be carefully selected to reduce the mutagenic effects over the genome [106]. Evolution of recessive alleles may pose negative impact over the performance of induced 
polyploid. Spindle inhibiting agents inducing less deleterious effects over the genome should be found and used [107]. DNA markers may be further used to determine allele frequency changes across the genome, and genotypes with low linkage drag should be selected to develop true-to-type polyploids [106]. Colchicine applications may also induce epigenetic changes, which may not be heritable. Hence, performance of induced polyploids may be investigated over several generations and across testing sites to assess the economic value of synthetic polyploid [108].

Slow progress of induced polyploidy after early induction of the chromosome set doubling event is the major hindrance for the low success rate in polyploid breeding. The mixoploid condition $(2 \times, 3 \times$ and $4 \times)$ in freshly developed material and subsequent generations reduced the performance, stability and fertility of induced polyploids [34], which was regarded as a major difficulty for commercializing synthetic polyploid forages. A recent study demonstrated that tetraploid barrel medic (Medicago truncatula Gärtner) had higher forage yield (106\%) than its diploid form, but derived lines across generations had highly variable fertility and stability [109]. However, selection of pure and stable polyploid genotypes in advanced generations may improve the performance of the induced polyploids. Selection for several generations could lead to increased frequency of tetraploid plants in Italian ryegrass [34]. As a result of tetraploid Lolium spp. having interesting results, it was not surprising being the first to be commercialized as new forage cultivars [32].

The stabilization of chromosome number after induced polyploidy requires time and may depend on accurately identifying stable offspring regarding their chromosome number. Tools such as flow cytometry may facilitate screening the hybrid-derived offspring with stable ploidy. Molecular techniques which may accurately determines changes such as those resulting from epigenetic interactions, or down- and up-regulation of key genes for yield and quality may assist on improving induced polyploid performance.

\section{Conclusions}

Polyploidy is a widespread phenomenon among forages. Research has shown that polyploid species have greater biomass yield, persistence, regrowth after grazing, and better tolerance to abiotic stresses than diploid species. Genetically polyploid organism carried multiple copies of alleles which may be helpful to increase allelic diversity and provide several evolutionary and adaptability advantages. Methods for induced polyploidy have been developed to increase biomass yield and improve foliage quality. The stability of induced polyploidy may be improved by selection for balanced chromosome pairing and disjunction. Induced polyploidy has also been used to increase fertility of interspecific hybrids between two cross-incompatible species. Research results suggested that this polyploidy approach may be pursued in forage breeding without any negative consequences. However, breeding of new cultivars using this approach needs to shorten the lengthy selection cycles from early chromosome doubling to stabilizing induced polyploidy and addressing both poor fertility and loss of vigor in following polyploid generations. A careful selection of anti-tubulin agent and its optimum concentration may be required to increase the frequency of successful polyploids with less deleterious mutations. DNA markers may be used for background selection to accurately select genotypes with lesser mutagenic effects. Confirmation of induced polyploid with balanced chromosome pairing (bivalent or quadrivalent) may be necessary, although it has been cumbersome through empirical methods. Flow cytometry is an alternative tool for confirmation of duplicated genome size. However, judging chromosomal pairing behavior may require pachytene analysis. Stability testing of induced hybrids under various agroclimatic conditions may be undertaken to accurately estimate the superiority of induced polyploids over the related diploids.

Author Contributions: Conceived the idea and wrote some sections, S.R.; made technical corrections in text and figures, updated technical terms and added new text in all drafts, elaborate sections and wrote new sections, R.O.; corrected 1st draft of the article and provided technical inputs throughout its writing, particularly in last version, D.P.M.; corrected several sections and added new section, W.R.C.; added new references throughout the text, W.K.; read manuscript and provided input in 
figures M.S., helped in writing first draft of article, U.W.; and made technical input in all drafts, S.W.H. All authors have read and agreed to the published version of the manuscript.

Funding: This review of research and other articles did not receive any grant funding.

Conflicts of Interest: The authors declare no conflict of interest.

\section{References}

1. Chen, Z.J. Molecular mechanisms of polyploidy and hybrid vigor. Trends Plant Sci. 2010, 15, 57-71. [CrossRef]

2. Shimizu-Inatsugi, R.; Terada, A.; Hirose, K.; Kudoh, H.; Sese, J.; Shimizu, K.K. Plant adaptive radiation mediated by polyploid plasticity in transcriptomes. Mol. Ecol. 2017, 26, 193-207. [CrossRef]

3. $\quad$ Estep, M.C.; McKain, M.R.; Diaz, D.V.; Zhong, J.; Hodge, J.G.; Hodkinson, T.R.; Layton, D.J.; Malcomber, S.T.; Pasquet, R.; Kellogg, E.A. Allopolyploidy, diversification, and the Miocene grassland expansion. Proc. Natl. Acad. Sci. USA 2014, 111, 15149-15154. [CrossRef]

4. Randhawa, M.S.; Singh, R.P.; Dreisigacker, S.; Bhavani, S.; Huerta-Espino, J.; Rouse, M.N.; Sandoval-Sanchez, M. Identification and validation of a common stem rust resistance locus in two bi-parental populations. Front. Plant Sci. 2018, 9, 1788. [CrossRef]

5. Rao, S.; Tian, Y.; Xia, X.; Li, Y.; Chen, J. Chromosome doubling mediates superior drought tolerance in Lycium ruthenicum via abscisic acid signaling. Hort. Res. 2020, 7, 40. [CrossRef]

6. Te Beest, M.; Le Roux, J.J.; Richardson, D.M.; Brysting, A.K.; Suda, J.; Kubešová, M.; Pyšek, P. The more the better? The role of polyploidy in facilitating plant invasions. Annal. Bot. 2012, 109, 19-45. [CrossRef] [PubMed]

7. Venial, L.R.; Mendonça, M.A.C.; Amaral-Silva, P.M.; Canal, G.B.; Passos, A.B.R.J.; Ferreira, A.; Soares, T.C.B.; Clarindo, W.R. Autotetraploid Coffeacanephora and auto-alloctaploid Coffeaa rabicafrom in vitro chromosome set doubling: New germplasms for Coffea. Front. Plant Sci. 2020, 11, 154. [CrossRef] [PubMed]

8. Dhooghe, E.; Van Laere, K.; Eeckhaut, T.; Leus, L.; Van Huylenbroeck, J. Mitotic chromosome doubling of plant tissues in vitro. Plant Cell Tissue Organ Cult. 2011, 104, 359-373. [CrossRef]

9. Bretagnolle, F.A.; Thompson, J.D. Gametes with the somatic chromosome number: Mechanisms of their formation and role in the evolution of autopolyploid plants. New Phytol. 1995, 129, 1-22. [CrossRef]

10. Sattler, M.C.; Carvalho, C.R.; Clarindo, W.R. The polyploidy and its key role in plant breeding. Planta 2016, 243, 281-296. [CrossRef] [PubMed]

11. Ciprian-Salcedo, G.C.; Jimenez-Davalos, J.; Zolla, G. Flow-cytometry applications in plant breeding. Rev. Perua. Biol. 2020, 27, 79-84. [CrossRef]

12. Rauf, S.; Sienkiewicz-Paderewska, D.; Malinowski, D.P.; Hussain, M.M.; Niazi, I.A.K.; Kausar, M. Forages: Ecology, breeding objectives and procedure. In Advances in Plant Breeding Strategies: Agronomic, Abiotic and Biotic Stress Traits; Al-Khayri, J.M., Jain, S.M., Johnson, D.V., Eds.; Springer: Cham, Switzerland, 2016; pp. 149-201.

13. Stebbins, G.L. The origin of the complex of Bromus carinatus and its phylogeographic implications. Gray Herb. Harv. Univ. 1947, 165, 42-55.

14. Stebbins, G.L. Chromosomes and evolution in the genus Bromus (Gramineae). Bot. Jahrb. Syst. Pflanzengesch. Pflanzengeogr. 1981, 102, 359-379.

15. Rao, S.R.; Kumar, A.; Purohit, J.; Khedasana, R.; Bewal, S. Cytogenetical investigations in colchicine induced tetraploids of Cyamopsis tetragonoloba L. Czech J. Genet. Plant Breed. 2010, 45, 143-154.

16. Niazi, I.A.K.; Rauf, S.; Teixeira da Silva, J.A.; Iqbal, Z.; Munir, H. Induced polyploidy in inter-subspecific maize hybrids to reduce heterosis breakdown and restore reproductive fertility. Grass Forage Sci. 2015, 70, 682-694. [CrossRef]

17. Corneillie, S.; De Storme, N.; Van Acker, R.; Fangel, J.U.; De Bruyne, M.; De Rycke, R.; Boerjan, W. Polyploidy affects plant growth and alters cell wall composition. Plant Physiol. 2019, 179, 74-87. [CrossRef] [PubMed]

18. Ardabili, G.S.; Zakaria, R.A.; Zare, N. In vitro induction of polyploidy in Sorghum bicolor L. Cytologia 2015, 80, 495-503. [CrossRef]

19. Poosamart, W.; Siniri, N.; Simia, S. Effects of colchicine concentration level and soaking period to induce polyploid mutation on five forage sorghum (Sorghum bicolor L. Moench) cultivars. J. Mahanakorn Veter. Med. 2015, 10, 99-110.

20. Simioni, C.; Valle, C.B. Meiotic analysis in induced tetraploids of Brachiari Adecumbens Stapf. Crop Breed. Appl. Biotechnol. 2011, 11, 43-49. [CrossRef]

21. De Souza-Kaneshima, A.M.; Simioni, C.; Felismino, M.F.; Mendes-Bonato, A.B.; Risso-Pascotto, C.; Pessim, C.; Pagliarini, M.S.; Do Valle, C.B. Meiotic behaviour in the first interspecific hybrids between Brachiaria brizantha and Brachiaria decumbens. Plant Breed. 2010, 129, 186-191. [CrossRef]

22. Pagliarini, M.S.; Carneiro Vieira, M.L.; Borges do Valle, C. Meiotic Behavior in Intra-and Interspecific Sexual and Somatic Polyploid Hybrids of Some Tropical Species. In Meiosis Molecular Mechanisms and Cytogenetic Diversity. 2012. Available online: https:/ / www.intechopen.com/books/meiosis-molecular-mechanisms-and-cytogenetic-diversity/meiotic-behavior-in-intraand-interspecific-tetraploid-sexual-and-somatic-hybrids-of-some-tropical-s (accessed on 28 October 2019).

23. Yu, C.Y.; Kim, H.S.; Rayburn, A.L.; Widholm, J.M.; Juvik, J.A. Chromosome doubling of the bioenergy crop, Miscanthus $\times$ giganteus. GCB Bioenergy 2009, 1, 404-412. [CrossRef]

24. Faleiro, F.G.; Kannan, B.; Altpeter, F. Regeneration of fertile, hexaploid, interspecific hybrids of elephant grass and pearl millet following treatment of embryogenic calli with antimitotic agents. Plant Cell Tissue Organ Cult. 2016, 124, 57-67. [CrossRef] 
25. Dabkevičienè, G.; Statkevičiūtè, G.; Mikaliūnienè, J.; Norkevičienė, E.; Kemešytè, V. Production of Trifolium pratense L. and T. hybridum L. tetraploid populations and assessment of their agrobiological charac-teristics. Zemdir. Agric. 2016, 103, 377-384. [CrossRef]

26. Dabkevičienè, G.; Kemešytè, V.; Statkevičiūtè, G.; Lemežienè, N.; Brazauskas, G. Autopolyploids in fodder grass breeding: Induction and field performance. Span. J. Agric. Res. 2017, 15, 20. [CrossRef]

27. Castillo, A.; Lopez Carro, B.; Dalla Rizza, M.; Reyno, R. Use of in vitro methods to induce autotetraploids in the native forage legume Trifolium polymorphum. In VII International Symposium on Production and Establishment of Micropropagated Plants; ISHS: Lavras, Minas Gerais, Brazil, 2017; pp. 73-80.

28. Silva, A.J.; Carvalho, C.R.; Clarindo, W.R. Chromosome set doubling and ploidy stability in synthetic auto- and allotetraploid of Eucalyptus: From in vitro condition to the field. Plant Cell Tissue Organ Cult. 2019, 138, 387-394. [CrossRef]

29. Dirihan, S.; Terho, P.; Helander, M.; Saikkonen, K. Efficient analysis of ploidy levels in plant evolutionary ecology. Caryologia 2013, 66, 251-256. [CrossRef]

30. Yun, L.; Yun, J.; Li, J.; Zheng, L.; Zhao, W.; Qi, L. Callus polyploidy induction and identification of Russian wild ryegrass. Acta Pratac. Sin. 2010, 19, 126-131.

31. Joshi, P.; Verma, R.C. High frequency production of colchicine induced autotetraploids in faba bean (Viciafaba L.). Cytologia 2004, 69, 141-147. [CrossRef]

32. Pereira, R.C.; Ferreira, M.T.M.; Davide, L.C.; Pasqual, M.; Mittelmann, A.; Techio, V.H. Chromosome duplication in Lolium multiflorum Lam. Crop Breed. Appl. Biotechnol. 2014, 14, 251-255. [CrossRef]

33. Yoon, S.; Aucar, S.; Hernlem, B.J.; Edme, S.; Palmer, N.; Sarath, G.; Mitchell, R.; Blumwald, E.; Tobias, C.M. Generation of octaploid switchgrass by seedling treatment with mitotic inhibitors. BioEnergy Res. 2017, 10, 344-352. [CrossRef]

34. Campos, J.M.S.; Davide, L.C.; Salgado, C.C.; Santos, F.C.; Costa, P.N.; Silva, P.S.; Pereira, A.V. In vitro induction of hexaploid plants from triploid hybrids of Pennisetum purpureum and Pennisetum glaucum. Plant Breed. 2009, 128, 101-104. [CrossRef]

35. Ishigaki, G.; Gondo, T.; Suenaga, K.; Akashi, R. Induction of tetraploid ruzigrass (Brachiaria ruziziensis) plants by colchicine treatment of in vitro multiple-shoot clumps and seedlings. Grassl. Sci. 2009, 55, 164-170. [CrossRef]

36. Timbó, A.L.D.O.; Souza, P.N.D.C.; Pereira, R.C.; Nunes, J.D.; Pinto, J.E.B.P.; SouzaSobrinho, F.D.; Davide, L.C. Obtaining tetraploid plants of ruzigrass (Brachiaria ruziziensis). R. Bras. Zootec. 2014, 43, 127-131. [CrossRef]

37. Głowacka, K.; Jeżowski, S.; Kaczmarek, Z. In vitro induction of polyploidy by colchicine treatment of shoots and preliminary characterisation of induced polyploids in two Miscanthus species. Ind. Crop. Prod. 2010, 32, 88-96. [CrossRef]

38. Niazi, I.A.K. Evaluation of Zea mays $\times$ Zea mexicana for High Fodder Yield. Ph.D. Thesis, University of Sargodha, Sargodha, Pakistan, 2016.

39. Abd El-Naby, Z.M.; Mohamed, N.A.; Radwan, K.H.; El-Khishin, D.A. Colchicine induction of polyploidy in Egyptian clover genotypes. J. Am. Sci. 2012, 8, 221-227.

40. Wilkins, P.W.; Lovatt, J.A. Gains in dry matter yield and herbage quality from breeding perennial ryegrass. Ir. J. Agric. Food Res. 2011, 50, 23-30.

41. Dhawan, O.P.; Lavania, U.C. Enhancing the productivity of secondary metabolites via induced polyploidy: A review. Euphytica 1996, 87, 81-89. [CrossRef]

42. Tulay, E.; Unal, M. Production of colchicine induced tetraploids in Vicia villosa roth. Caryologia 2010, 63, 292-303. [CrossRef]

43. Dabkevičienè, G.; Kemešytè, V.; Lemežienè, N.; Butkutè, B. Production of slender cocksfoot (Dactylis polygama H.) tetraploid populations and their assessment for agromorphological characteristics. Zemdir. Agric. 2013, 100, 303-310. [CrossRef]

44. Balocchi, O.A.; López, I.F. Herbage production, nutritive value and grazing preference of diploid and tetraploid perennial ryegrass cultivars (Lolium perenne L.). Chil. J. Agric. Res. 2009, 69, 331-339. [CrossRef]

45. Price, S.C. Tetraploid corn and methods of its production. U.S. Patent No. 4,75,910, 10 November 1987.

46. Nadel, D.; Nadel, M.; Nadel, B. High Yield Maize Derivatives. U.S. Patent Application 12/004,894, 25 June 2009.

47. Smith, K.F.; McFarlane, N.M.; Croft, V.M.; Trigg, P.J.; Kearney, G.A. The effects of ploidy and seed mass on the emergence and early vigour of perennial ryegrass (Lolium perenne L.) cultivars. Aust. J. Exp. Agric. 2003, 43, 481-486. [CrossRef]

48. Bartek, M.S.; Hodnett, G.L.; Burson, B.L.; Stelly, D.M.; Rooney, W.L. Pollen Tube Growth After Intergeneric Pollinations of iap-Homozygous Sorghum. Crop Sci. 2012, 52, 1553-1560. [CrossRef]

49. Ardabili, G.S.; Zakaria, R.A.; Zare, N. Polyploidy induction and its effects on some morpho-physiologic characteristics in sorghum (Sorghum bicolor cv. KFS2). Iran. J. Crop Sci. 2014, 16, 151-164.

50. Pathak, S.; Malaviya, D.R.; Roy, A.K.; Dwivedi, K.; Kaushal, P. Multifoliate Leaf Formation in Induced Tetraploids of Trifolium alexandrinum L. Cytologia 2015, 80, 59-66. [CrossRef]

51. Chaves, A.L.A.; Raquel, B.; Chiavegatto, M.L.; Gavilanes, F.R.G.B.; Vânia, H.T. Effect of polyploidy on the leaf epidermis structure of Cynodondactylon (L.) Pers. (Poaceae). Biologia 2018, 73, 1007-1013. [CrossRef]

52. Zielinski, M.L.; Scheid, O.M. Meiosis in polyploid plants. In Polyploidy and Genome Evolution; Springer: Berlin/Heidelberg, Germany, 2012; pp. 33-55.

53. Comai, L. The advantages and disadvantages of being polyploid. Nat. Rev. Genet. 2005, 6, 836-846. [CrossRef]

54. Skiebe, K.; Seliger, P. Isoenzymes and their importance for breeding autopolyploids. Plant Breed. 1990, 105, 106-111. [CrossRef]

55. Valizadeh, M.; Mohayeji, M.; Yasinzadeh, N.; Nasrullazadeh, S.; Moghaddam, M. Genetic diversity of synthetic alfalfa generations and cultivars using tetrasomic inherited allozyme markers. J. Agric. Sci. Tech. 2011, 13, 425-430. 
56. Corts, M.R.; Morales, M.C.; Martinez, C. Variation of PGM and IDH isozymes for identification of alfalfa varieties. Euphytica 2000, 112, 137-143. [CrossRef]

57. Jalaly, H.M.; Valizadeh, M.; Ahmadi, M.; Nabizadeh, H.; Moharramnejad, S.; Moghaddam, M. Discrimination of alfalfa half-sib families by allozyme banding pattern and its relationship with forage yield attributes. J. Biodiv. Environ. Sci. 1990, 6, 344-350.

58. Fjellstrom, R.G.; Steiner, J.J.; Beuselinck, P.R. Tetrasomic linkage mapping of RFLP, PCR, and isozyme loci in Lotus corniculatus L. Crop Sci. 2003, 43, 1006-1020. [CrossRef]

59. Diwan, N.; Bouton, J.H.; Kochert, G.; Cregan, P.B. Mapping of simple sequence repeat (SSR) DNA markers in diploid and tetraploid alfalfa. Theoret. Appl. Genet. 2000, 101, 165-172. [CrossRef]

60. Julier, B.; Flajoulot, S.; Barre, P.; Cardinet, G.; Santoni, S.; Huguet, T.; Huyghe, C. Construction of two genetic linkage maps in cultivated tetraploid alfalfa (Medicago sativa) using microsatellite and AFLP markers. BMC Plant Biol. 2003, 3, 9. [CrossRef]

61. Stein, J.; Quarin, C.L.; Martínez, E.J.; Pessino, S.C.; Ortiz, J.P.A. Tetraploid races of Paspalum notatum show polysomic inheritance and preferential chromosome pairing around the apospory-controlling locus. Theor. Appl. Genet. 2004, 109, 186-191. [CrossRef] [PubMed]

62. Begheyn, R.F.; Lübberstedt, T.; Studer, B. Haploid and doubled haploid techniques in perennial ryegrass (Lolium perenne L.) to advance research and breeding. Agronomy 2016, 6, 60. [CrossRef]

63. Capomaccio, S.; Veronesi, F.; Rosellini, D. Polyploidization and gene expression in Medicago sativa. In Sustainable Use of Genetic Diversity in Forage and Turf Breeding; Springer: Dordrecht, The Netherlands, 2010; pp. 397-401.

64. Rosellini, D.; Ferradini, N.; Allegrucci, S.; Capomaccio, S.; Zago, E.D.; Leonetti, P.; Veronesi, F. Sexual polyploidization in Medicago sativa L.: Impact on the phenotype, gene transcription, and genome methylation. G3-Genes Genom. Genet. 2016, 6, 925-938.

65. Molin, W.T.; Meyers, S.P.; Baer, G.R.; Schrader, L.E. Ploidy effects in isogenic populations of alfalfa. II. Photosynthesis, chloroplast number, ribulose-1,5-bisphosphate carboxylase, chlorophyll, and DNA in protoplasts. Plant Physiol. 1982, 70, 1710-1714. [CrossRef]

66. Mo, L.; Chen, J.; Lou, X.; Xu, Q.; Dong, R.; Tong, Z.; Huang, H.; Lin, E. Colchicine-induced polyploidy in Rhododendron fortune Lindl. Plants 2020, 9, 424. [CrossRef]

67. Pei, Y.; Yao, N.; He, L.; Deng, D.; Li, W.; Zhang, W. Comparative study of the morphological, physiological and molecular characteristics between diploid and tetraploid radish (Raphunas sativus L.). Scient. Hort. 2019, 257, 108739. [CrossRef]

68. Santos, F.C.; Guyot, R.; Do Valle, C.B.; Chiari, L.; Techio, V.H.; Heslop-Harrison, P.; Vanzela, A.L.L. Chromosomal distribution and evolution of abundant retrotransposons in plants: Gypsy elements in diploid and polyploid Brachiaria forage grasses. Chromosome Res. 2015, 23, 571-582. [CrossRef] [PubMed]

69. Oberprieler, C.; Talianova, M.; Griesenbeck, J. Effects of polyploidy on the coordination of gene expression between organellar and nuclear genomes in Leucanthemum Mill. (Compositae, Anthemideae). Ecol. Evol. 2019, 9, 9100-9110. [CrossRef] [PubMed]

70. Murashige, T.; Skoog, F. A revised medium for rapid growth and bioassays with tobacco tissue cultures. Physiol. Plant. 1962, 15, 473-497. [CrossRef]

71. Nair, R.M. Developing tetraploid perennial ryegrass (Lolium perenne L.) populations. N. Z. J. Agric. Res. 2004, 47, 45-49. [CrossRef]

72. Mendes-Bonato, A.B.; Felismino, M.F.; Kaneshima, A.S.; Pessim, C.; Calisto, V.; Pagliarini, M.S.; do Valle, C.B. Abnormal meiosis in tetraploid genotypes of Brachiaria brizantha (Poaceae) induced by colchicine: Its implications for breeding. J. Appl. Genet. 2009, 50, 83-87. [CrossRef]

73. Dos Reis, G.B.; Ishii, T.; Fuchs, J.; Houben, A.; Davide, L.C. Tissue-specific genome instability in synthetic interspecific hybrids of Pennisetum purpureum (Napier grass) and Pennisetum glaucum (pearl millet) is caused by micronucleation. Chromosome Res. 2016, 24, 285-297. [CrossRef]

74. Simioni, C.; Wittmann, M.T.S.; Dall, M.; Guerra, D. Selection for increasing $2 n$ gamete production in red clover. Crop Breed. Appl. Biotech. 2004, 4, 217-220. [CrossRef]

75. Pereira, R.C.; Davide, L.C.; Techio, V.H.; Timbó, A.L.O. Chromosome doubling of grasses: An alternative to plant breeding. Ciência Rural 2012, 42, 1278-1285. [CrossRef]

76. Baduel, P.; Bray, S.; Vallejo-Marin, M.; Kolář, F.; Yant, L. The "polyploid hop": Shifting challenges and opportunities over the evolutionary lifespan of genome duplications. Front. Ecol. Evol. 2018, 6, 117. [CrossRef]

77. Frank, A.B.; Berdahl, J.D. Gas exchange and water relations in diploid and tetraploid Russian wildrye. Crop Sci. 2001, 41, 87-92. [CrossRef]

78. Ribotta, A.N.; Griffa, S.M.; Díaz, D.; Carloni, E.J.; Colomba, E.L.; Tommasino, E.A.; Grunberg, K. Selecting salt-tolerant clones and evaluating genetic variability to obtain parents of new diploid and tetraploid germplasm in rhodesgrass (Chloris gayana L.). S. Afr. J. Bot. 2013, 84, 88-93. [CrossRef]

79. Tozer, K.N.; Carswell, K.; Griffiths, W.M.; Crush, J.R.; Cameron, C.A.; Chapman, D.F.; Popay, A.; King, W. Growth responses of diploid and tetraploid perennial ryegrass (Lolium perenne) to soil-moisture deficit, defoliation and a root-feeding invertebrate. Crop Pasture Sci. 2017, 68, 632-642. [CrossRef]

80. Sugiyama, S. Differentiation in competitive ability and cold tolerance between diploid and tetraploid cultivars in Lolium perenne. Euphytica 1998, 103, 55-59. [CrossRef]

81. Chandra, A.; Dube, A. Assessment of ploidy level on stress tolerance of Cenchrus species based on leaf photosynthetic characteristics. Acta Physiol. Plant. 2009, 31, 1003-1013. [CrossRef] 
82. Sugiyama, S.I. Responses of shoot growth and survival to water stress gradient in diploid and tetraploid populations of Lolium multiflorum and L. perenne. Grassl. Sci. 2006, 52, 155-160. [CrossRef]

83. Anwar, S. Genetic-phenotypic variability and correlation between morphology anatomy physiology characteristics and dry matter yield of polyploidized forage grasses under aluminum stressed condition. Anim. Product. 2007, 9, $23-29$.

84. Marzougui, N.; Boubaya, A.; Guasmi, F.; Elfalleh, W.; Touil, L.; Ferchichi, A.; Beji, M. Influence of artificial polyploidy on the salt stress tolerance of Trigonella foenum-graecum L. in Tunisia. Acta Bot. Gall. 2010, 157, 295-303. [CrossRef]

85. Meng, H.B.; Jiang, S.S.; Hua, S.J.; Lin, X.Y.; Li, Y.L.; Guo, W.L.; Jiang, L.X. Comparison between a tetraploid turnip and its diploid progenitor (Brassica rapa L.): The adaptation to salinity stress. Agric. Sci. China 2011, 10, 363-375. [CrossRef]

86. Franco, M.F.; Colabelli, M.N.; Petigrosso, L.R.; De Battista, J.P.; Echeverría, M.M. Evaluation of infection with endophytes in seeds of forage species with different levels of ploidy. N. Z. J. Agric. Res. 2015, 58, 181-189. [CrossRef]

87. Kemesyte, V.; Statkeviciute, G.; Brazauskas, G. Perennial ryegrass yield performance under abiotic stress. Crop Sci. 2017, 57, 1935-1940. [CrossRef]

88. Lee, M.A.; Howard-Andrews, V.; Chester, M. Resistance of multiple diploid and tetraploid perennial ryegrass (Lolium perenne L.) varieties to three projected drought scenarios for the UK in 2080. Agronomy 2019, 9, 159. [CrossRef]

89. Chandra, A.; Dubey, A. Effect of ploidy levels on the activities of $\Delta 1$-pyrroline-5-carboxylate synthetase, superoxide dismutase and peroxidase in Cenchrus species grown under water stress. Plant Physiol. Biochem. 2010, 48, 27-34. [CrossRef]

90. Arseniuk, E. Triticale abiotic stresses-An overview. Commun. Agric. Appl. Biol. Sci. 2015, 79, 82-100.

91. Ryan, P.R.; Dong, D.; Teuber, F.; Wendler, N.; Mühling, K.H.; Liu, J.; Xu, M.; Salvador Moreno, N.; You, J.; Maurer, H.P.; et al. Assessing how the aluminum-resistance traits in wheat and rye transfer to hexaploid and octoploid triticale. Front. Plant Sci. 2018, 9, 1334. [CrossRef]

92. Niazi, I.A.K.; Avais, R.; Rauf, S.; Teixeira da Silva, J.A.; Afzal, M. Simultaneous selection for stem borer resistance and forage related traits in maize (Zea mays ssp. mays L.) $\times$ teosinte (Zea mays ssp. mexicana L.) derived populations. Crop Prot. 2014, 57, 27-34.

93. Dewey, D.R. Some applications and misapplications of induced polyploidy to plant breeding. In Polyploidy; Springer: Boston, MA, USA, 1980; pp. 445-470.

94. Den Nijs, A.P.M.; Stephenson, A.G. Potential of unreduced pollen for breeding tetraploid perennial ryegrass. In Sexual Reproduction in Higher Plants; Springer: Berlin/Heidelberg, Germany, 1988; pp. 131-136.

95. Rios, E.F.; Kenworthy, K.E.; Munoz, P.R. Association of phenotypic traits with ploidy and genome size in annual ryegrass. Crop Sci. 2015, 55, 2078-2090. [CrossRef]

96. Sugiyama, S.I. Polyploidy and cellular mechanisms changing leaf size: Comparison of diploid and autotetraploid populations in two species of Lolium. Ann. Bot. 2005, 96, 931-938. [CrossRef]

97. Wang, Y.; Bigelow, C.A.; Jiang, Y. Ploidy level and DNA content of perennial ryegrass germplasm as determined by flow cytometry. HortScience 2009, 44, 2049-2052. [CrossRef]

98. Burns, G.A.; Gilliland, T.J.; Grogan, D.; O'Kiely, P. Comparison of the agronomic effects of maturity and ploidy in perennial ryegrass. In Grassland: An European Resource; Polskie Towarzystwo Łakarskie: Lublin, Poland, 2012; pp. 349-351.

99. Akinroluyo, O.K.; Jaškūnė, K.; Kemešytè, V.; Statkevičiūtè, G. Drought stress response of Westerwolths ryegrass (Lolium multiflorum ssp. multiflorum) cultivars differing in their ploidy level. Zemdir. Agric. 2020, 107, 221-230.

100. O'Donovan, M.; Delaby, L.A. comparison of perennial ryegrass cultivars differing in heading date and grass ploidy with spring calving dairy cows grazed at two different stocking rates. Anim. Res. 2005, 54, 337-350. [CrossRef]

101. Solomon, J.K.; Macoon, B.; Lang, D.J.; Vann, R.C.; Ward, S. Cattle grazing preference among tetraploid and diploid annual ryegrass cultivars. Crop Sci. 2014, 54, 430-438. [CrossRef]

102. Hume, D.E.; Hickey, M.J.; Lyons, T.B.; Baird, D.B. Agronomic performance and water-soluble carbohydrate expression of selected ryegrasses at two locations in New Zealand. N. Z. J. Agric. Res. 2010, 53, 37-57. [CrossRef]

103. Kenworthy, K.E.; Reith, P.E.; Prine, G.M.; Blount, A.R.; Quesenberry, K.H. Registration of 'FL Red', a later-maturing tetraploid annual ryegrass. J. Plant Reg. 2017, 11, 46-50. [CrossRef]

104. Smith, K.F.; Simpson, R.J.; Culvenor, R.A.; Humphreys, M.O.; Prud'Homme, M.P.; Oram, R.N. The effects of ploidy and a phenotype conferring a high water-soluble carbohydrate concentration on carbohydrate accumulation, nutritive value and morphology of perennial ryegrass (Lolium perenne L.). J. Agric. Sci. 2001, 136, 65-74. [CrossRef]

105. Pereira, R.C.; Santos, N.D.S.; Bustamante, F.D.O.; Mittelmann, A.; Techio, V.H. Stability in chromosome number and DNA content in synthetic tetraploids of Lolium multiflorum after two generations of selection. Ciência Rural 2017, 47, 2. [CrossRef]

106. Ren-Hua, J.I.; Zhong-Ling, C.I.; Lin-Qing, Y.U.; LIU, S.-N.; Chen, S.R. Chromosome doubling technique of forage in vitro and its application progress in breeding. Pratacult. Anim. Husband. 2011, 9, 33-39.

107. Hegarty, M.; Coate, J.; Sherman-Broyles, S.; Abbott, R.; Hiscock, S.; Doyle, J. Lessons from natural and artificial polyploids in higher plants. Cytogenet. Genome Res. 2013, 140, 204-225. [CrossRef] [PubMed]

108. Münzbergová, Z. Colchicine application significantly affects plant performance in the second generation of synthetic polyploids and its effects vary between populations. Ann. Bot. 2017, 120, 329-339. [CrossRef]

109. Innes, L.A.; Denton, M.D.; Dundas, I.S.; Peck, D.M.; Humphries, A.W. The effect of ploidy number on vigor, productivity, and potential adaptation to climate change in annual Medicago species. Crop Sci. 2020, 60. [CrossRef] 